\title{
LOGIKA FUZZY DALAM TEKNIK PERAMALAN SECARA STATISTIK
}

\author{
Deddy Barnabas Lasfeto
}

\begin{abstract}
Abstrak :
Selama ini, metode peramalan secara konvensional yang digunakan adalah analisis regresi. Oleh karena itu, dicoba untuk dibandingkan kinerja metode konvensionil dalam hal ini analisis regresi dengan metode sistem cerdas, dalam hal ini adalah logika fuzzy. Dengan dapat dianalisisnya kinerja kedua sistem peramalan tersebut, maka user dapat memilih metode yang mana yang sebaiknya digunakan jika melakukan suatu proses peramalan. Tujuan dalam penelitian ini adalah membandingkan kinerja dari fuzzy logic dan regresi dalam analisis peramalan suatu variabel forcastum dari satu atau lebih variabel bebas (independent variable).

Input yang diperlukan yang sesuai yaitu mengisi ukuran range dan memilih type fungsi keanggotaan input $X 1, X 2, X 3, \ldots, X \mathrm{n}$ serta parameter yang diperlukan. Hal serupa juga dilakukan untuk variabel tak bebas $Y$. Hal yang sama input $X 1, X 2$ dan $Y$ untuk menentukan peramalan dengan regresi berganda. Input $X 1, X 2$ dan $Y$ secara simulasi akan ditampilkan. Untuk melihat kinerja secara keseluruhan dalam teknik peramalan. Untuk regresi berganda ini, baik secara fuzzy maupun dengan teknik konvensional maka, dihitung nilai kesalahan rata-rata yang berdasarkan kesalahan relative masing-masing Y untuk setiap input data.

Dari hasil analisis ini, diperoleh bahwa pada regresi berganda, nilai kesalahan relative ratarata pada metode Fuzzy sedikit lebih besar dibandingkan dengan metode regresi konvensional, yakni sebesar 3\%. Dapat dikatakan bahwa Metode regresi konvensional lebih baik dibandingkan dengan metode fuzzy dalam tekni peramalan ini.
\end{abstract}

Kata Kunci : Fuzzy, Statistik, Regresi.

\section{PENDAHULUAN}

Salah satu metode komputasi yang cukup berkembang saat ini adalah sistem cerdas. Dalam teknologi informasi, sistem cerdas dapat juga digunakan untuk melakukan peramalan. Salah satu metode dalam sistem cerdas yang dapat digunakan untuk melakukan peramalan adalah menggunakan logika fuzzy.

Selama ini, metode peramalan secara konvensional yang digunakan adalah analisis regresi. Oleh karena itu, dicoba untuk dibandingkan kinerja metode konvensionil dalam hal ini analisis regresi dengan metode sistem cerdas, dalam hal ini adalah logika fuzzy.
Dengan dapat dianalisisnya kinerja kedua sistem peramalan tersebut, maka user dapat memilih metode yang mana yang sebaiknya digunakan jika melakukan suatu proses peramalan.

Regresi merupakan metode statistik. Seperti yang diketahui di dalam statistik sifat dasar dari modalitas suatu variabel diklasifikasikan sebagai kualitatif atau kuantitatif. Secara spesifik, adalah kuantitatif jika modalitas yang berhubungan adalah nilai numerik. Dengan berfokus pada variabelvariabel kuantitatif, adalah sangat lazim untuk mengukur variabel-variabel kuantitatif terkait 


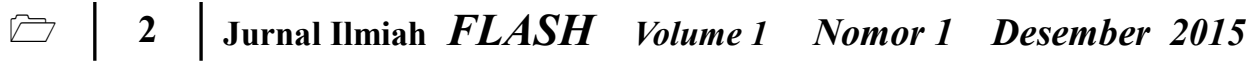

dengan nilai tunggal, yaitu modalitas mereka adalah nilai yang tepat. Akan tetapi, untuk mendapatkan ukuran-ukuran yang tepat sangat sulit didapatkan. Metode statistik didasari oleh teori probabilitas yang merepresentasikan ketidakpastian. Sumber yang relevan dari ketidak tepatan dapat ditemukan di dalam fase pemrosesan data yang terdiri dari penghitungan suatu estimasi dari kuantitas. Hasil dari setiap pemrosesan data tidak pernah akurat $100 \%$ (Kreinovich, Lakejev, Rohn \& Kahl 1997). Faktanya, dengan nilai aktual dari kuantitas yang diukur, ini berbeda dari hasil pengukurannya. Jika ada informasi tentang kesalahan hasil dari pemrosesan data, maka diketahui bahwa nilai aktual (yang tidak diketahui) dari kuantitas yang diukur berada pada suatu interval nilai tertentu.

\section{METODE PENELITIAN}

Logika fuzzy sebagai representasi fungsi keanggotaan variabel bebas $X 1, X 2, \quad X 3, \ldots$, $X \mathrm{n}$ sebagai input serta representasi fungsi keanggotaan variabel bebas dan $Y$ variable tak bebas sebagai output. Setelah menentukan representasi fungsi keanggotaan kemudian defuzzyfikasi pada komposisi aturan Mamdani, yang dalam hal ini menggunakan Metode Centroid). Untuk persoalan regresi berganda, rumus yang sangat berperan adalah $y=a+b 1$ $\mathrm{X} 1+\mathrm{b} 2 \mathrm{X} 2+\ldots+\mu$

Sistem yang baik adalah suatu sistem yang benar, efisien dan mudah pengoperasiannya serta menarik. Agar tercapai tujuan membangun sistem yang baik, maka proses perlu disusun analisis kebutuhan yang meliputi :

Input yang diperlukan yang sesuai yaitu mengisi ukuran range dan memilih type fungsi keanggotaan input $X 1, X 2, X 3, \ldots, X \mathrm{n}$ serta parameter yang diperlukan. Hal serupa juga dilakukan untuk variabel tak bebas Y. Hal yang sama input $X 1, X 2$ dan $Y$ untuk menentukan peramalan dengan regresi berganda. Input $X 1$, $X 2$ dan $Y$ secara simulasi akan ditampilkan. adalah :

Adapun prosedur pemrogramannya
1. Menentukan input maupun output yang akan digunakan dalam membangun logika fuzzy, yaitu membuat FIS Editor input $X 1$ dan $X 2$ serta output $Y$.

2. Menentukan Fungsi keanggotaan variabel input $X 1$.

3. Menentukan Fungsi keanggotaan variabel input $X 2$.

4. Menentukan Fungsi keanggotaan variabel output $Y$.

5. Menyusun aturan fuzzy.

6. Defuzzyfikasi pada komposisi aturan Mamdani, yang dalam hal ini menggunakan Metode Centroid.

7. Menghitung konstanta $b 1, b 2$.

8. Menghitung peramalan $Y$.

\section{HASIL DAN PEMBAHASAN}

Untuk melihat kinerja kedua metode dalam regresi berganda, diperlukan dua variabel input dan satu variabel output. Dalam contoh kasus ini, diambil data variabel ouput (y)/ variabel terikat adalah Data Peringkat Kimia, sedangkan variabel input/ variabel bebas masisng-masing adalah NIlai Ujian sebagai $\mathrm{X}_{1}$ dan Frekuensi Membolos sebagai $\mathrm{X}_{2}$, seperti ditunjukkan dalam tabel 1 :

Tabel 1. Studi Kasus Data peringkat kimia, nilai ujian \& frekuensi membolos mahasiswa

\begin{tabular}{|c|c|c|c|}
\hline Siswa & $\begin{array}{c}\text { Peringkat } \\
\text { Kimia }(\mathrm{Y})\end{array}$ & $\begin{array}{c}\text { Nilai Ujian } \\
\left(\mathrm{X}^{1}\right)\end{array}$ & $\begin{array}{c}\text { Frekuensi } \\
\text { Membolos } \\
\left(\mathrm{X}^{2}\right)\end{array}$ \\
\hline 1 & 85 & 65 & 1 \\
2 & 74 & 50 & 7 \\
3 & 76 & 55 & 5 \\
4 & 90 & 70 & 2 \\
5 & 85 & 65 & 6 \\
6 & 87 & 70 & 3 \\
7 & 94 & 55 & 2 \\
8 & 98 & 70 & 5 \\
9 & 81 & 55 & 4 \\
10 & 91 & 70 & 3 \\
11 & 76 & 50 & 1 \\
12 & 74 & 55 & 4 \\
\hline
\end{tabular}


Akan dilakukan analisis dengan metode Fuzzy dan Regresi konvensional Untuk menentukan nilai Y. Dari data metah ini, terlihat bahwa range data sebagai berikut :

Peringkat Kimia : : $74-98$

Nilai Ujian : $50-70$

Frekuensi membolos : $1-7$
Dengan Metode Fuzzy sebagai berikut :

Dari Data ini dibuat Fuzzy Inference System (FIS) dengan menentukan Variabel input adalah NIlai Ujian $\left(X_{1}\right)$ dan Frekuensi Membolos $\left(\mathrm{X}_{2}\right)$, sedangkan variabel outputnya adalah Peringkat Kimia (Y). Dengan menggunakan Program MATLAB, FIS editor seperti tampak pada gambar 1 :

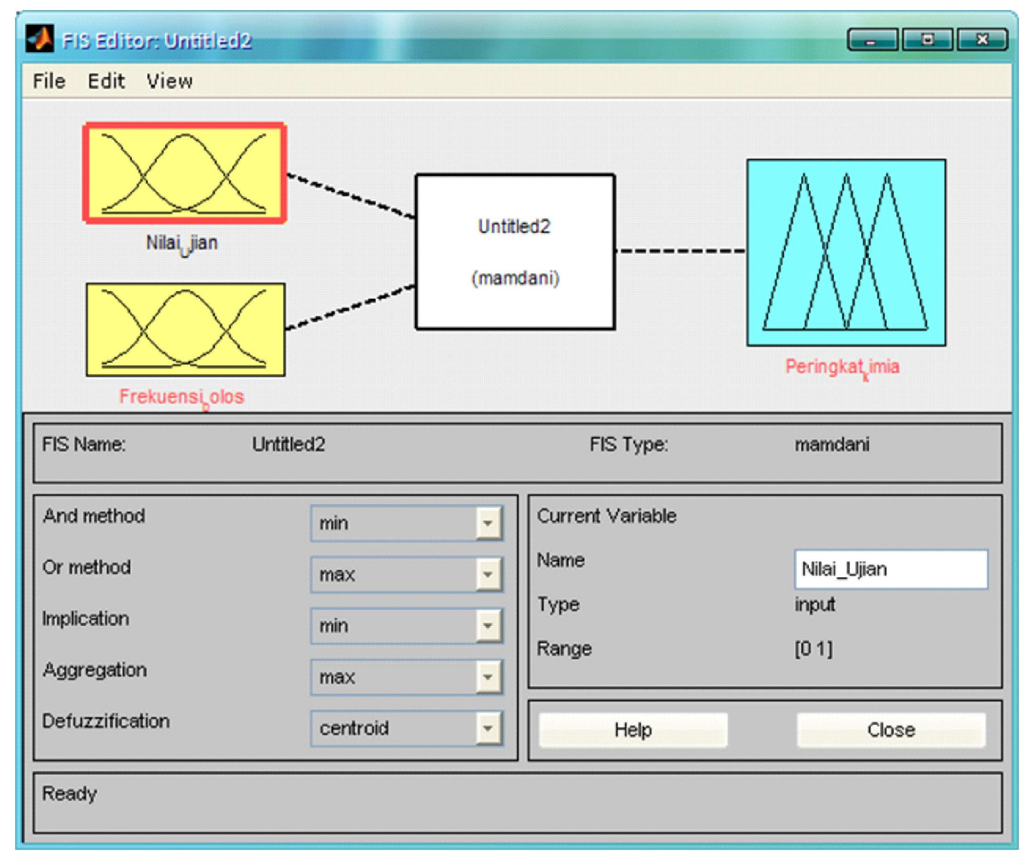

Gambar 1. FIS Editor Regresi Berganda

Aturan Fuzzy adalah sebagai berikut dimana $\mathrm{X} 1=$ nilai ujian ; $\mathrm{X} 2$ = frekuensi bolos; $\mathrm{Y}=$ Peringkat Kimia :

1. Jika $X 1$ masuk rendah dan $X 2$ sedikit maka $Y$ sedang.

2. Jika $X 1$ masuk rendah dan $X 2$ sedang maka $Y$ rendah.

3. Jika $X 1$ masuk rendah dan $X 2$ banyak maka perlu Y rendah.

4. Jika $X 1$ masuk tandard dan $X 2$ sedikit maka perlu Y sedang.

5. Jika $X 1$ masuk tandard dan $X 2$ sedang maka perlu Y sedang.

6. Jika $X 1$ masuk tandard dan $X 2$ banyak maka perlu Y sedang.
7. Jika $X 1$ masuk tinggi dan $X 2$ sedikit maka perlu $\mathrm{Y}$ tinggi.

8. Jika $X 1$ masuk tinggi dan $X 2$ sedang maka perlu $Y$ tinggi.

9. Jika $X 1$ masuk tinggi dan $X 2$ banyak maka perlu $\mathrm{Y}$ yang sedang.

Dengan nilai kognitif yang dirumuskan tersebut, maka ditentukan fungsi keanggotaan fuzzy, yakni Fungsi yang dipakai adalah Fungsi Segitiga. Hasil tampilan Fungsi Keanggotaan Fuzzy (Fuzzy membership function) adalah sebagai berikut:

Himpunan anggota (Membership function) Untuk variabel NIlai Ujian adalah : \{rendah, standar, tinggi\}. Range keanggotaannya adalah 50 sampai 70 . Seperti tampak pada gambar 2: 


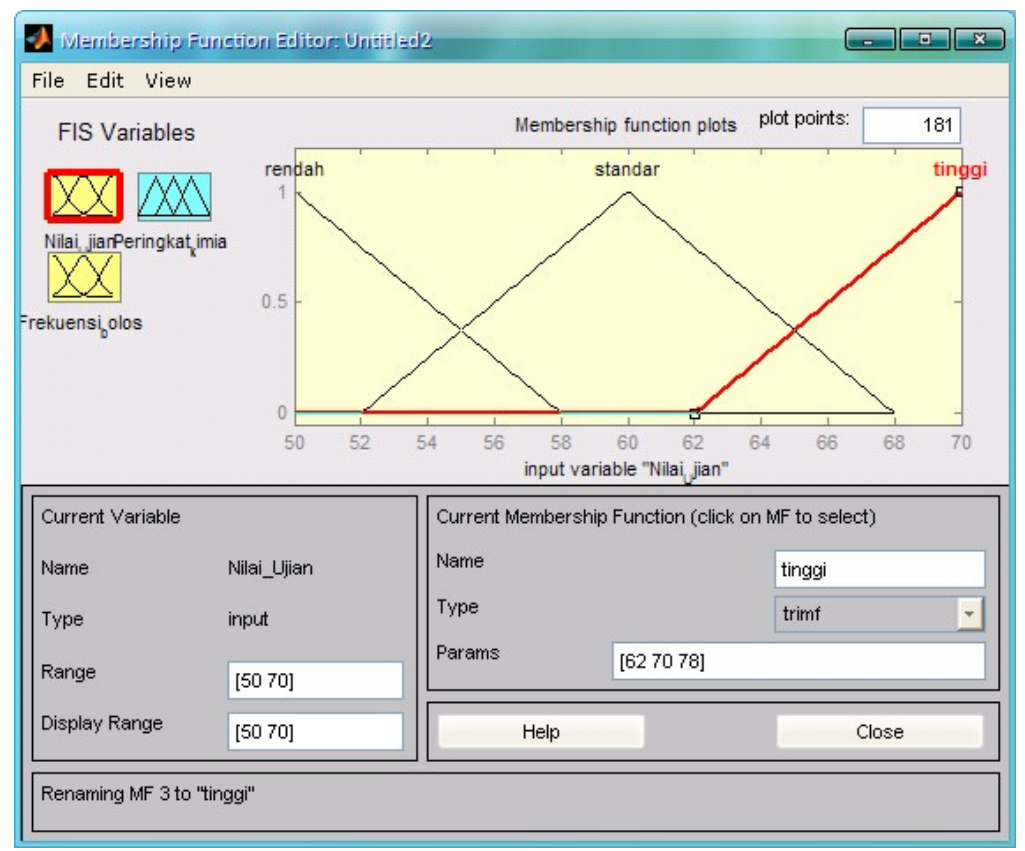

Gambar 2. Fungsi Keanggotaan Input NIlai Ujian

Untuk Variabel input Frekuensi Bolos, Fungsi sedang, banyak\}, dengan range adalah 1 sampai keanggotaannya adalah himpunan : \{sedikit, 7 seperti terlihat dalam gambar 3.

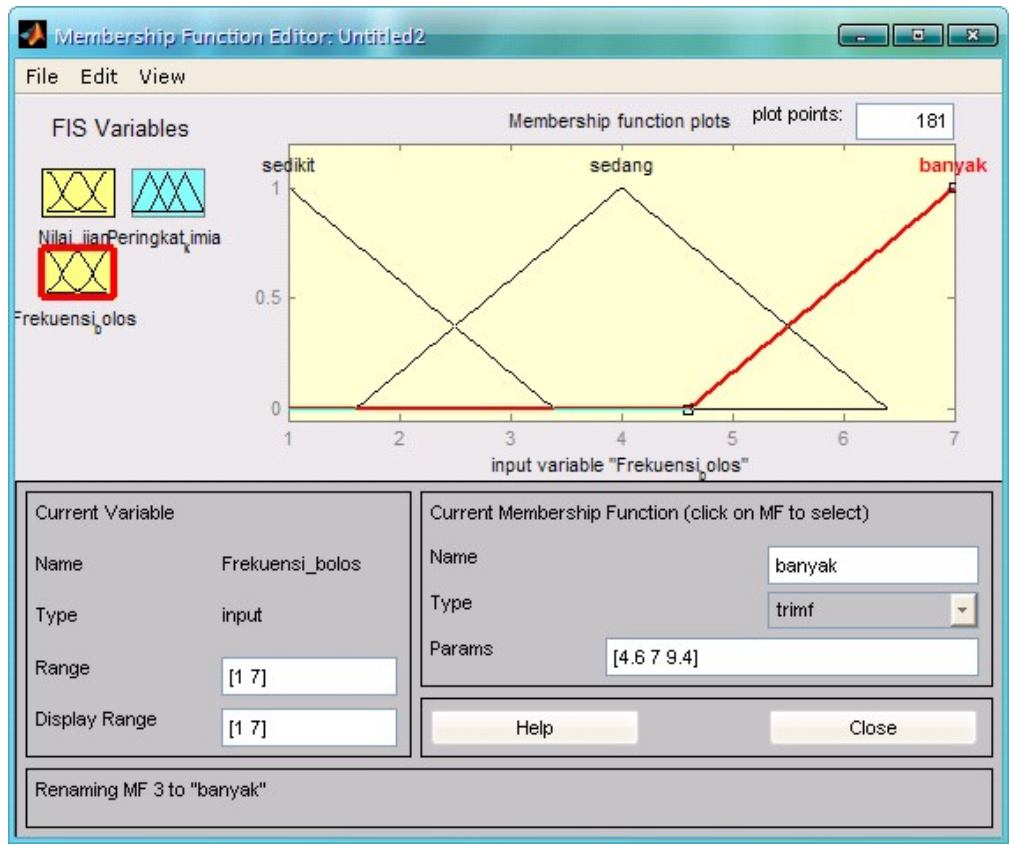

Gambar 3. Fungsi Keanggotaan input Frekuensi Bolos 
Variabel Output Peringkat kimia memiliki tinggi\} dengan nilai range adalah 74 sampai 98 himpunan keanggotaan : \{rendah, sedang, seperti tampak pada gambar 4.

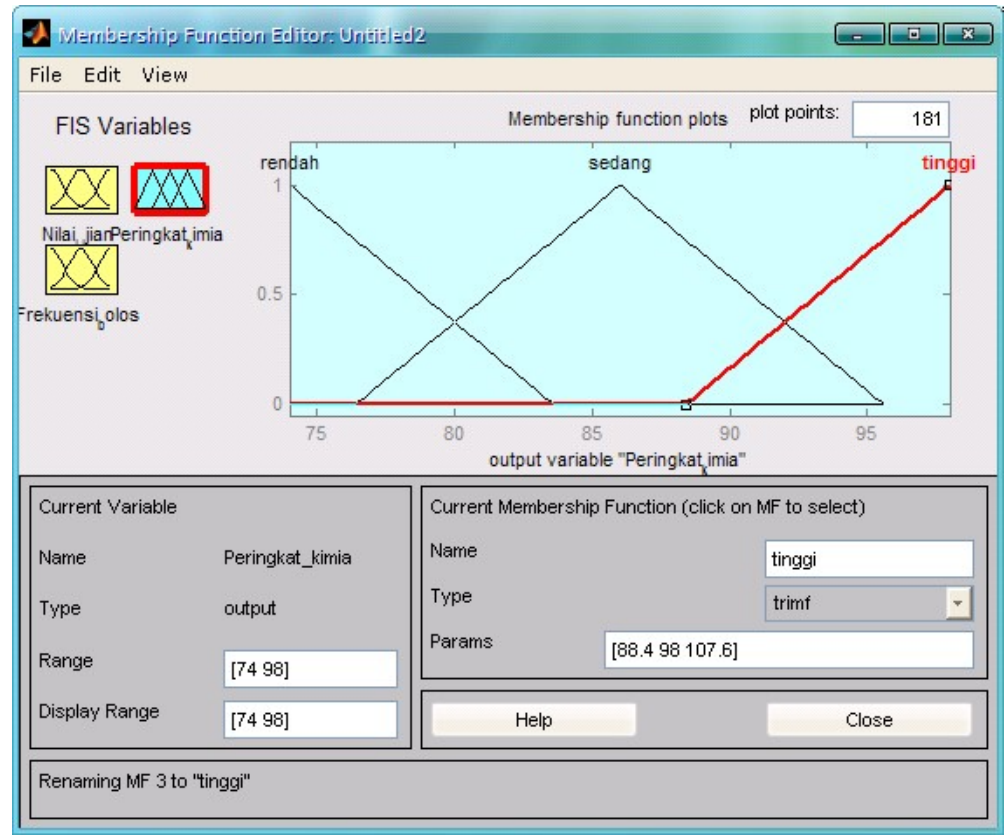

\section{Gambar 4. Fungsi Keanggotaan Variabel output " Peringkat Kimia"}

Dengan merumuskan fungsi keanggotaan dirumuskan sebelumnya. Tampilan Hasil dengan masing-masing variabel, maka perlu Logika Fuzzy adalah seperti tampak pada dimasukkan aturan-aturan fuzzy yang telah gambar 5.

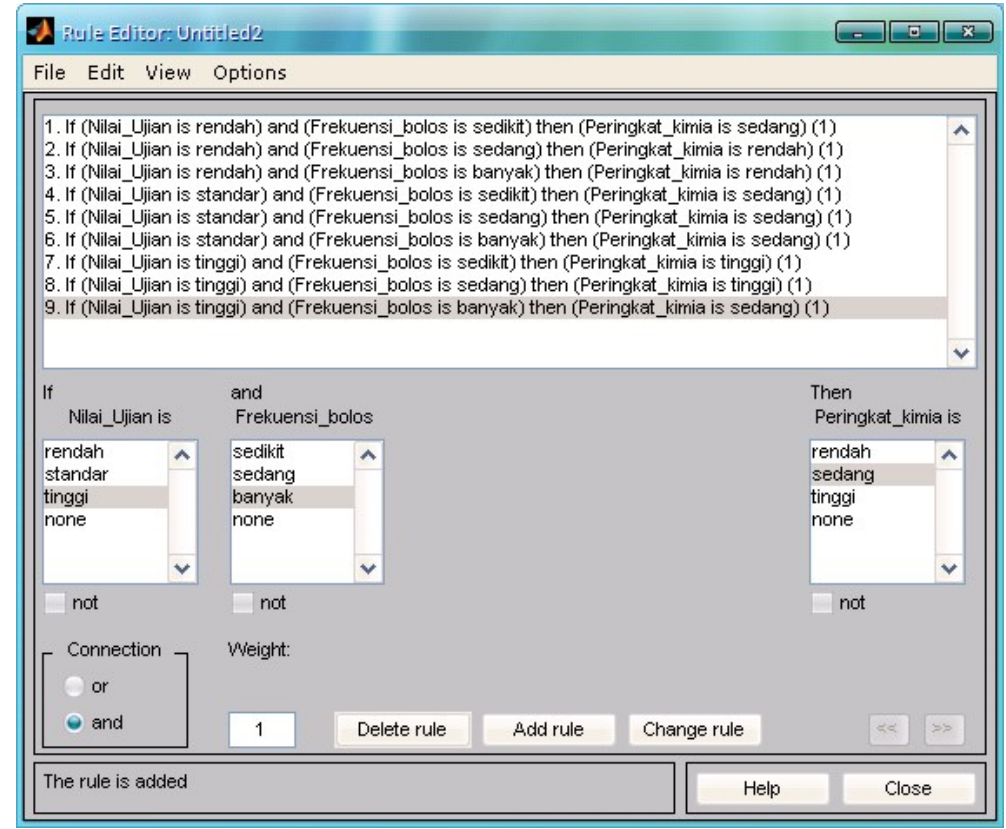

Gambar 5. Fuzzy Rule Editor 


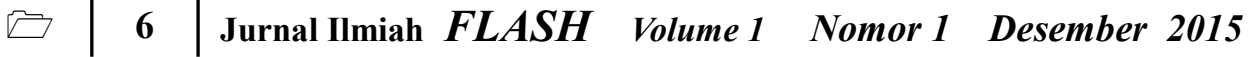

Outputnya Fuzzy Regresi seperti tampak pada gambar 6.:

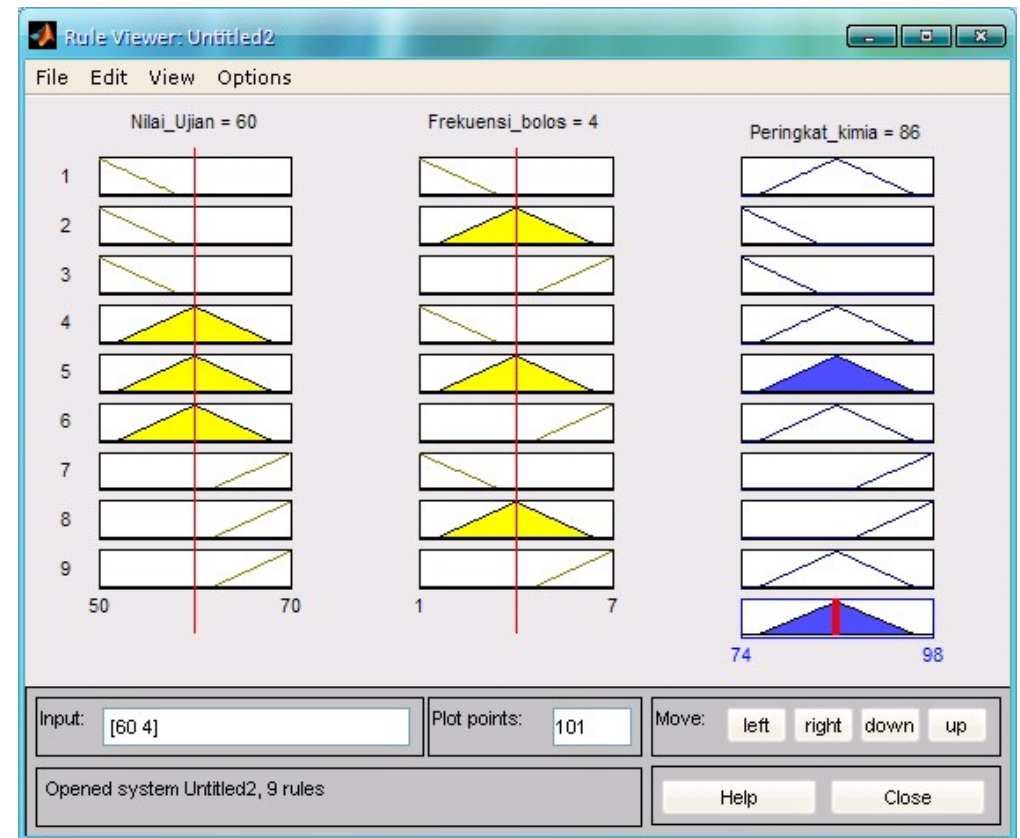

Gambar 6. Output Fuzzy Regresi Berganda

Hasil fuzzy Regression ini bila dibuat dalam suatu tabel, tampak pada tabel 2 .

Tabel 2. Hasil Perhitungan Fuzzy Untuk nilai $Y$

\begin{tabular}{|r|r|r|r|}
\hline $\begin{array}{r}\text { Peringkat } \\
\text { Kimia (Y) }\end{array}$ & $\begin{array}{c}\text { Nilai Ujian } \\
(\mathrm{X} 1)\end{array}$ & $\begin{array}{c}\text { Frekuensi } \\
\text { membolos } \\
(\mathrm{X} 2)\end{array}$ & Y (Fuzzy) \\
\hline 85 & 65 & 1 & 88.1 \\
\hline 74 & 50 & 7 & 77.1 \\
\hline 76 & 55 & 5 & 83.9 \\
\hline 90 & 70 & 2 & 94.5 \\
\hline 85 & 65 & 6 & 86.9 \\
\hline 87 & 70 & 3 & 94.5 \\
\hline 94 & 55 & 2 & 85.1 \\
\hline 98 & 70 & 5 & 90.7 \\
\hline 81 & 55 & 4 & 83.8 \\
\hline 91 & 70 & 3 & 94.5 \\
\hline 76 & 50 & 1 & 86 \\
\hline 74 & 55 & 4 & 83.8 \\
\hline
\end{tabular}

Nilai Peringkat Kimia (Y) hasil dari analisis Fuzzy akan dibandingkan dengan NIlai Y sebenarnya dari data mentah, yakni dengan menentukan nilai kesalahan relatifnya.

Secara statistic dengan metode regresi konvensional, maka data tersebut dilakukan Analisis dengan menggunakan metode Regresi Linear Berganda. Analisis ini menempatkan Variabel NIlai Ujian $\left(X_{1}\right)$ dan Frekuensi Membolos $\left(\mathrm{X}_{2}\right)$ sebagai variabel bebas dan Variabel Peringkat Kimia (Y) sebagai Variabel Terikatnya. Hasil Analisis dengan metode regresi menggunakan Program Komputer SPSS adalah seperti tampak pada gambar 7 . 


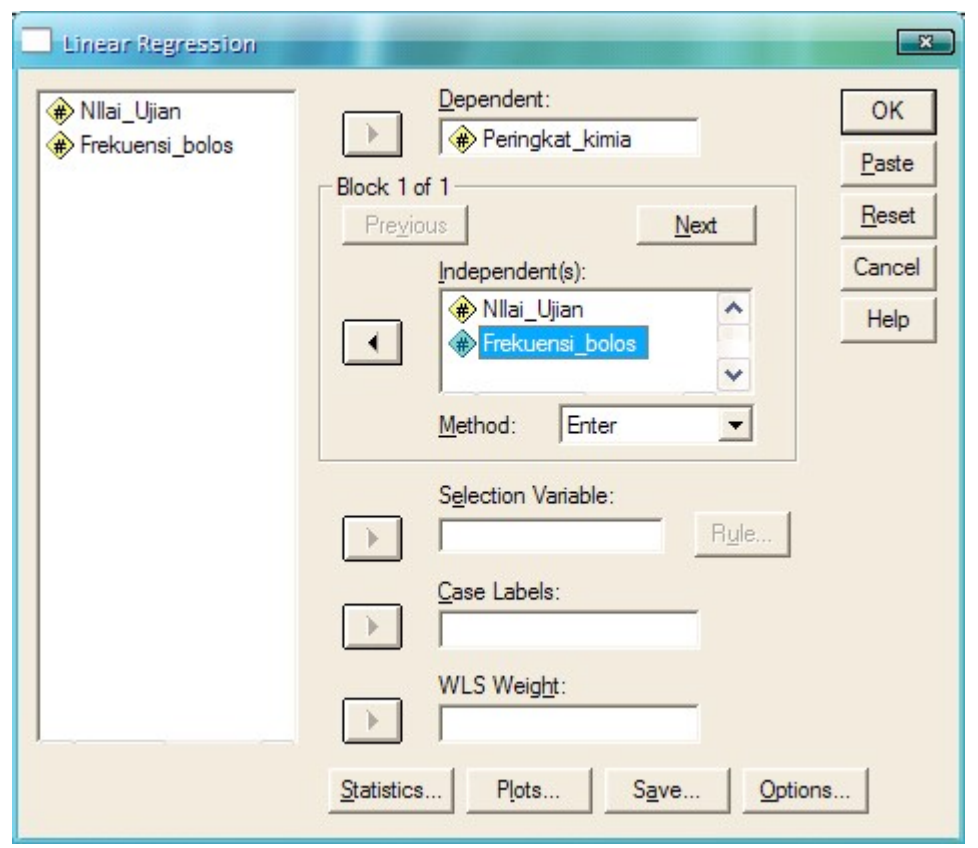

Gambar 7. Linear Regression

Dari analisis ini diperoleh hasil :

\section{Coefficients $^{\mathrm{a}}$}

\begin{tabular}{|c|c|c|c|c|c|c|}
\hline \multirow[b]{2}{*}{ Model } & & \multicolumn{2}{|c|}{$\begin{array}{l}\text { Unstandardized } \\
\text { Coefficients }\end{array}$} & \multirow{2}{*}{$\begin{array}{c}\begin{array}{c}\text { Standardized } \\
\text { Coefficients }\end{array} \\
\text { Beta }\end{array}$} & \multirow[b]{2}{*}{$\mathrm{t}$} & \multirow[b]{2}{*}{ Sig. } \\
\hline & & B & Std. Error & & & \\
\hline & (Constant) & 43.009 & 14.429 & & 2.981 & .015 \\
\hline & Nllai_Ujian & .712 & .221 & .718 & 3.222 & .010 \\
\hline & Frekuensi_bolos & -.571 & .940 & -.135 & -.607 & .559 \\
\hline
\end{tabular}

a. Dependent Variable: Peringkat_kimia

Diperoleh hubungan sebagai Berikut :

$$
Y \text { regresi }=43.009+0.712 X_{1}-0.571 X_{2}
$$

Berdasarkan Persamaan regresi ini, maka akan dihitung nilai $Y$ regresi ntuk setiap Variabel bebas $\mathrm{X}_{1}$ dan $\mathrm{X}_{2}$ seperti terlihat dalam tabel 3 :
Tabel 3. Hasil Perhitungan Y regresi konvensional

\begin{tabular}{|r|r|r|r|}
\hline $\begin{array}{c}\text { Peringkat } \\
\text { Kimia (Y) }\end{array}$ & $\begin{array}{c}\text { Nilai Ujian } \\
\text { (X1) }\end{array}$ & $\begin{array}{c}\text { Frekuensi } \\
\text { membolos } \\
\text { (X2) }\end{array}$ & $\begin{array}{c}\text { Y } \\
\text { (Regresi) }\end{array}$ \\
\hline 85 & 65 & 1 & 88.718 \\
\hline 74 & 50 & 7 & 74.612 \\
\hline 76 & 55 & 5 & 79.314 \\
\hline 90 & 70 & 2 & 91.707 \\
\hline 85 & 65 & 6 & 85.863 \\
\hline
\end{tabular}




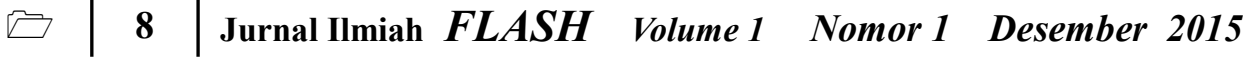

\begin{tabular}{|l|l|l|l|}
\hline 87 & 70 & 3 & 91.136 \\
\hline 94 & 55 & 2 & 81.027 \\
\hline 98 & 70 & 5 & 89.994 \\
\hline 81 & 55 & 4 & 79.885 \\
\hline 91 & 70 & 3 & 91.136 \\
\hline 76 & 50 & 1 & 78.038 \\
\hline 74 & 55 & 4 & 79.885 \\
\hline
\end{tabular}

Kesalahan relatif (relative error) adalah ukuran kesalahan dalam kaitannya dengan pengukuran,

$$
\begin{aligned}
& e_{r}=\left|\frac{X_{s}-X_{a}}{X_{s}}\right| \\
& \text { dengan: er }=\text { kesalahan relatif } \\
& \text { Xs } \quad=\text { nilai sebenarnya } \\
& \text { Xa } \quad=\text { nilai perhitungan }
\end{aligned}
$$

dalam teknik peramalan untuk regresi berganda ini, baik secara fuzzy maupun dengan teknik konvensional maka, dihitung nilai kesalahan rata-rata yang berdasarkan kesalahan relative masing-masing $\mathrm{Y}$ untuk setiap input data.

Dari kedua metode yang digunakan dalam peramalan ini, telah diperoleh nilai $\mathrm{Y}$ dari masing-masing metode. Untuk Melihat kinerja kedua metode ini, maka dihitung nilai Kesalahan (Error) Relatif dari masing-masing data dengan menggunakan Rumus :

Untuk melihat rata-rata kesalahan relatif yang terjadi pada suatu data dinyatakan dengan:

Rata-rata kesalahan relatif $=\frac{\text { jumlah kesalahan relatif }}{\text { jumlah data }}$

Secara keseluruhan perbandingan analisis Peramalan dengan metode regresi dan fuzzy pada dua variabel input dan satu output (Rgeresi linear berganda) ditampilkan dalam tabel 4 .

Tabel 4. Hasil Perhitungan Error Relative pada Regresi Berganda

\begin{tabular}{|c|c|c|c|c|c|c|}
\hline$(\mathrm{Y})$ & $(\mathrm{X} 1)$ & $(\mathrm{X} 2)$ & $\begin{array}{c}\mathrm{Y} \\
(\text { Fuzzy) }\end{array}$ & Y regresi & $\begin{array}{c}\text { Error relative } \\
\text { Fuzzy }\end{array}$ & $\begin{array}{c}\text { Error relative } \\
\text { Regresi }\end{array}$ \\
\hline \hline 85 & 65 & 1 & 88.1 & 88.718 & 0.036470588 & 0.043741176 \\
\hline 74 & 50 & 7 & 77.1 & 74.612 & 0.041891892 & 0.00827027 \\
\hline 76 & 55 & 5 & 83.9 & 79.314 & 0.103947368 & 0.043605263 \\
\hline 90 & 70 & 2 & 94.5 & 91.707 & 0.05 & 0.018966667 \\
\hline 85 & 65 & 6 & 86.9 & 85.863 & 0.022352941 & 0.010152941 \\
\hline 87 & 70 & 3 & 94.5 & 91.136 & 0.086206897 & 0.04754023 \\
\hline 94 & 55 & 2 & 85.1 & 81.027 & 0.094680851 & 0.138010638 \\
\hline 98 & 70 & 5 & 90.7 & 89.994 & 0.074489796 & 0.081693878 \\
\hline 81 & 55 & 4 & 83.8 & 79.885 & 0.034567901 & 0.013765432 \\
\hline 91 & 70 & 3 & 94.5 & 91.136 & 0.038461538 & 0.001494505 \\
\hline 76 & 50 & 1 & 86 & 78.038 & 0.131578947 & 0.026815789 \\
\hline 74 & 55 & 4 & 83.8 & 79.885 & 0.132432432 & 0.079527027 \\
\hline \hline
\end{tabular}


Dari hasil analisis ini, diperoleh bahwa pada regresi berganda, nilai kesalahan relative rata-rata pada metode Fuzzy sedikit lebih besar dibandingkan dengan metode regresi konvensional, yakni sebesar 3\%. Dapat dikatakan bahwa Metode regresi konvensional lebih baik dibandingkan dengan metode fuzzy dalam tekni peramalan ini.

\section{KESIMPULAN DAN SARAN}

\section{Kesimpulan:}

1. Metode Fuzzy dapat dipakai juga sebagai alat dalam analisis peramalan secara statistik

2. Kinerja dan hasil analisis peramalan (forcasting analysis) dengan menggunaan metode fuzzy memiliki nilai kesalahan sedikit lebih besar dibandingkan dengan metode regresi. Akan tetapi, bila ditemukan funggsi keanggotaan yang lebih tepat, dan pengetahuan teknis serta pengalaman dalam bidang ilmu yang diteliti untuk penentuan aturan fuzzy yang lebih benar, maka kemungkinan kesalahan metode fuzzy akan sama bahkan bisa lebih kecil dibandingkan dengan metode regresi.

\section{Saran:}

Dalam penelitian ini, terdapat beberapa temuan yang dapat dijadikan saran untuk pengembangan lebih lanjut sebagai berikut:

1. Dalam rangka memperluas aplikasi Logika fuzzy untuk teknik peramalan, maka diperlukan suatu teknik pengujian awal dari data mentah yang akan diolah untuk menentukan fungsi keanggotaan fuzzy yang tepat digunakan sesuai karakteristik data tersebut.

2. Diperlukan Pengalaman dan pengetahuan teknis yang cukup sesuai kasus yang diteliti, dalam rangka penentuan fungsi keanggotaan dan aturan-aturan Fuzzy (Fuzzy Rules), yang dapat dipakai untuk teknik peramalan menggunakan metode fuzzy.

\section{DAFTAR PUSTAKA}

Kusumadewi, S. 2003, Artificiall Intelligence : Teknik dan Aplikasinya. Graha Ilmu, Yogyakarta.

Kusumadewi, S., 2002, Analisis Desain Sistem Fuzzy Menggunakan tool Box Matlab, Penerbit Graha Ilmu, Yogyakarta.

Kusumadewi, S., Purnomo, H., 2004, Aplikasi Logika Fuzzy Untuk Pendukung Keputusan, Penerbit Graha Ilmu, Yogyakarta.

Supranto, J. 1994, Statistik Teori dan Aplikasi Edisi Kelima. Erlangga, Jakarta.

Supriyono, 2007. Analisis Perbandingan Logika Fuzzy dengan Regresi Berganda Sebagai Alat Peramalan. Proceeding Seminar Nasional III SDM Teknologi Nuklir, Yogyakarta.

Sutrisno, 2011. Analisis Perbandingan Fuzzy Regresi dengan Regresi Berganda KOnvensional Sebagai Alat Peramalan, Seminar Nasional Teknologi Informasi \& Komunikasi Terapan 2011 (Semantik 2011) ISBN 979-26-0255-0

The MATLAB Curriculum Series, 1992, The Student Edition of Matlab, Prentice Hall, Inc, New Jersey.

Wati,S.E, Sebayang,D., Sitepu,R. 2013, Perbandingan Logika Fuzzy dengan Regresi Linear Berganda dalam Peramalan Jumlah Produksi, Saintia Matematika, Vol.1 No.03 (273-284). 